\title{
Exploring the Potential of a Virtual Undergraduate Library Collection Based on the Hierarchical Interface to LC Classification
}

\section{Adam Chandler and Jim LeBlanc}

Adam Chandler (alc28@cornell.edu) is Information Technology Librarian, Library Technical Services, Cornell University Library, Ithaca. N.Y.; Jim LeBlanc (jdl8@cornell.edu) is Head, Database Management Services, Library Technical Services, Cornell University Library, Ithaca, N.Y.

The authors wish to thank Stephen Davis and Bob Wolven at Columbia University for their assistance with this project, and Karen Calhoun at Cornell for her advice and encouragement as well as the original idea of testing the feasibility of adapting the Columbia HILCC model for use with a Cornell print collection. They also wish to thank the libraries of Columbia University, the University of Illinois at Urbana-Champaign, Indiana University, and the University of Washington for their quick and gracious response to our request for data, as well as their Cornell colleague, Phil Davis, for his expertise and advice on the use of Pearson correlations.
The Hierarchical Interface to Library of Congress Classification (HILCC) is a system developed by the Columbia University Library to leverage call number data from the MARC holdings records in Columbia's online catalog to create a structured, hierarchical menuing system that provides subject access to the library's electronic resources. In this paper, the authors describe a research initiative at the Cornell University Library to discover if the Columbia HILCC scheme can be used as developed or in modified form to create a virtual undergraduate print collection outside the context of the traditional online catalog. Their results indicate that, with certain adjustments, an HILCC model can indeed, be used to represent the holdings of a large research library's undergraduate collection of approximately 150,000 titles, but that such a model is not infinitely scalable and may require a new approach to browsing such a large information space.

Tn 1997, a working group of staff from Columbia University Library's Bibliographic Control Department and Library Systems Office set out to build a hierarchical interface to Library of Congress classification (HILCC). ${ }^{1}$ The project's aim was "to assess the potential of using the Library of Congress classification numbers as provided in standard catalog records to generate a structured, hierarchical menuing system for subject access to resources in the Libraries' electronic collection." "The group sought to leverage Columbia's MARC catalog data to permit "Web-based access to the Libraries' electronic resources outside the context of the OPAC." With help from reference staff and selectors, they created a classification mapping table to link discrete ranges in the Library of Congress classification schedules to entries in a three-, and occasionally four-, tiered subject tree. Simultaneously, the group developed a Web interface that would give users access to data extracted weekly from catalog records via this multilevel subject hierarchy. In the end, Columbia produced a HILCC model that provided access to some 5,000 electronic resources by way of 541 distinct subject categories. ${ }^{4}$

In his 2002 article, "HILCC: A Hierarchical Interface to Library of Congress Classification," Davis reflected on the challenges of testing HILCC's effectiveness and overall value. He also questioned the project's scalability- 
"what may seem useful and manageable against a list of 5,000 electronic titles may look quite different when the list has grown to 50,000 or more." ${ }^{5}$ Davis invited other institutions to pick up where Columbia left off, to take Columbia's mapping tables and rework them for their own collections and within their own institutional contexts. In 2004, the Cornell University Library accepted Columbia's invitation and began to explore the theoretical possibility of using HILCC to create a virtual undergraduate collection of Cornell's print material. This essay presents the results and conclusions of that investigation.

\section{Applicability of the Columbia Model to Cornell's Undergraduate Collection}

Like most large research libraries, the Cornell Library is facing a serious space problem, especially on the central campus, where academic real estate is at an all-time premium. The most common means of dealing with this space crunch is to transfer lesser-used material to offsite storage facilities, as well as to merge and reorganize those collections that remain onsite. As the Association of Research Libraries (ARL) noted in 1999, "Most ARL libraries already house a significant amount of material in offsite storage facilities, and the pace of both new construction and renovation of existing structures has accelerated during the past decade." ${ }^{. \prime}$ This trend continues unabated, and there is no indication that it will lessen in coming decades. On May 18, 2005, for example, the University of Texas at Austin Libraries announced that they are "relocating the Undergraduate Library (UGL) to other discipline-specific campus libraries in their system as the first step in the process of transforming the Flawn Academic Center (FAC) into an integrated, learning commons."

Thus, ARL institutions can benefit from studying ways to create print collections without regard for physical contiguity of the collections' individual elements, collections that transcend the limits of storage locations - that are virtual collections of physical items.
The question the authors sought to answer was "Can Cornell use Columbia HILCC mapping to represent Cornell's current undergraduate print collection of approximately 150,000 titles-that is, would the Columbia mapping be transferable from one research library's e-resource collection to another research library's print collection and, perhaps more importantly, would it scale?"

The HILCC mapping tables identify alpha-numeric call number ranges in the LC classification schedules that correspond to subject categories in the system's user interface. Each unique subject string is assigned a numeric label in the table (here called a "subject code"). Although classification ranges are mapped to one and only one unique subject string, these hierarchical subject categories are often the product of more than one LC classification range.

Table 1 presents an excerpt from Columbia's HILCC charts that deals with LC's "A" schedule and Columbia's "General" subject categories. Each row is numbered and indicates a unique range in the LC classification. The range itself is recorded in the "Class . .." columns. The HILCC subject string is recorded in the "Category. .." columns. The last column contains the subject code, which links single or multiple rows to a single HILCC subject string, as applicable. For example, rows 342 and 343 in the excerpted table represent the LC classification ranges AC0 through AC799 and AC900 through AC1100, both mapped to the Columbia HILCC subject string "General—Collections \& Series (General) and numerically labeled with the subject code 1270.

In order to apply the Columbia mapping scheme to the titles in Cornell's undergraduate library, the authors extracted all the call numbers from the undergraduate collection, using a program written by Peter Hoyt from the Cornell University Library Systems Office. They wrote a Perl script to match each call number to a range in the Columbia HILCC tables to derive the corresponding HILCC subject string and increment the count. ${ }^{8}$ The authors then output the results as a delimited file for analysis.

The results of running the Cornell undergraduate library's call numbers against the Columbia HILCC scheme

Table 1. Excerpt from Columbia University Library's HILCC mapping table

\begin{tabular}{lcccrcl}
\hline Row & Class & Class & Class & Class & & Subject \\
ID & IA & IN & 2A & 2N & Category 1 & Category 2 \\
342 & AC & 0.0000 & AC & 799.9990 & General & Collections \& Series (General) \\
233 & AC & 800.0000 & AC & 899.9990 & General & Dissertation Indexes \\
343 & AC & 900.0000 & AC & 1100.9990 & General & Collections \& Series (General) \\
344 & AE & 0.0000 & AE & 90.9990 & General & Encyclopedias (General) \\
345 & AG & 0.0000 & AG & 600.9990 & General & Dictionaries (General)
\end{tabular}

Notes: Taken from "Columbia University Digital Library Projects: Hierarchical Interface to LC Classification, Arranged by Class Number Range 03/05/04," www.columbia.edu/cu/libraries/inside/projects/metadata/hilcc/newfiles/class.html (accessed Sept. 2, 2005). No third-, fourth-, and fifth-level subject categories appear in this table excerpt. 
were not promising. In many cases, the number of titles assigned to individual subject strings represented what might be construed as a reasonably manageable retrieval set; however, in other cases, the number of titles assigned to individual subject strings was quite high.

Table 2 illustrates the incremental breakdown of titles per subject string for both Cornell and Columbia. The first column in the table lists hit rate ranges, from no titles retrieved for a given subject string to a maximum range of 10,001 to 15,000 titles retrieved. The second column records the number of subject strings that fell into these retrieval spans for the Cornell undergraduate collection. The third column gives this number as a percentage of the total number of HILCC categories. The fourth and fifth columns provide the results for Columbia's HILCC scheme. Although the number of titles in several of the retrieval sets were similar to those extracted by Columbia for their e-resource collection, Cornell's use of Columbia's HILCC scheme resulted in several subject categories that comprised more than 1,000 titles, 10 subject categories that yielded more than 2,500 titles, and 2 subject categories that, if searched in a live database, would return more than 10,000 title hits. At the same time, some 42 percent of all Columbia HILCC subject categories yielded 10 or fewer titles, with 121 categories retrieving no results at all. This histogram suggests that using the Columbia HILCC scheme, as is, would not lead to optimal results if applied to Cornell's undergraduate print collection-at least not with that collection's current content. Imagining an effective interface, given current technology, that would accommodate retrieval sets of this size using a structured hierarchical menu system is difficult.

The authors did speculate, however, that Cornell might be able to modify Columbia's HILCC scheme to better fit the test case. Before starting to edit the mapping tables, though, they investigated the potential applicability of a revised HILCC scheme for other libraries' undergraduate collections. They solicited data from four other ARL libraries (the Columbia University Library, the University of Illinois at Urbana-Champaign Library, the Indiana University Libraries, and the University of Washington Libraries), ran their call numbers through the Perl scripts described above, and derived a Pearson correlation of the results. The correlation shows the relative similarities in number of titles per subject category among these library collections, using a count of the number of titles that map to a given HILCC subject category for each of the sample libraries and comparing the numbers. The tendency was similarity between institutions; that is, a given category that had a high number of titles at one institution was likely to have a high number of titles at other institutions. Based on the results of this analysis, the authors went forward with the revision of Columbia's HILCC scheme, confident that the retailored tables would be generally useful to other libraries who wish to build further on Columbia's or Cornell's work.

\section{The Cornell Model}

In order to create a more usable HILCC scheme for Cornell's test collection, the authors needed to make some assumptions. First of all, how many titles encompassed by a single HILCC subject string are too many? Second, at what point does the hypothetical user interface contain too many subjects - too many branches and hierarchical levels on the subject tree-if modifying a HILCC scheme requires splitting the strings into further categories and subcategories? The authors decided on two mutually sup-

Table 2. Number of titles per HILCC subject: Cornell and Columbia

\begin{tabular}{|c|c|c|c|c|}
\hline $\begin{array}{l}\text { Titles } \\
\text { per subject }\end{array}$ & $\begin{array}{c}\text { Cornell scheme } \\
\text { distribution }\end{array}$ & $\%$ & $\begin{array}{c}\text { Columbia scheme } \\
\text { distribution }\end{array}$ & $\%$ \\
\hline 0 & 121 & 22 & 166 & 31 \\
\hline $1-10$ & 108 & 20 & 118 & 22 \\
\hline $11-50$ & 102 & 19 & 111 & 21 \\
\hline $51-100$ & 56 & 10 & 39 & 7 \\
\hline $101-250$ & 57 & 11 & 52 & 10 \\
\hline $251-500$ & 35 & 6 & 20 & 4 \\
\hline $501-1,000$ & 27 & 5 & 22 & 4 \\
\hline $1,001-2,500$ & 25 & 5 & 10 & 2 \\
\hline $2,501-5,000$ & 7 & 1 & 2 & $<1$ \\
\hline $5,001-10,000$ & 1 & $<1$ & 1 & $<1$ \\
\hline $10,001-15,000$ & 2 & $<1$ & 0 & 0 \\
\hline Total titles & 150,200 & & 64,830 & \\
\hline Mean titles/subject & 210 & & 120 & \\
\hline Median titles/subject & 16 & & 8 & \\
\hline Standard deviation & 844 & & 171 & \\
\hline No HILCC hit & 7993 & & 570 & \\
\hline
\end{tabular}


portive and presumably manageable parameters to address these concerns: editing Columbia's HILCC tables in such a way that no subject string would apply to more than 1,000 or fewer than 10 titles in Cornell's undergraduate library. Reducing the higher hit rates would necessarily result in the creation of more subject categories. However, combining categories that originally returned very few or no title hits would decrease the number of subject categories and, hopefully, counterbalance the effects of this expansion. As Columbia had done, the Cornell researchers opted to use the LC classification schedules for guidance on how to split or merge categories logically. When new subject category names were required, they would, for efficiency's sake, assign whatever seemed most appropriate without consultation with colleagues from other departments (though actual implementation of a revised HILCC scheme to build a live user interface would call for broader input along the lines of Columbia's implementation model). Finally, the authors decided to examine the physical material in situ, rather than through automated methods, since they had only a general notion about how best to approach the reorganization of the tables and no clear idea about how easy or difficult it would be to slice and dice extremely narrow classification ranges containing hundreds of titles.

The work of restructuring the Columbia HILCC tables for use with Cornell's undergraduate collection took roughly 65 real-time hours and resulted in a revamped scheme of 500 subject strings $(8$ percent fewer than Columbia
HILCC) in a five-level subject tree (one level deeper than Columbia HILCC). No subject string encompassed more than 1,000 titles, and only 4 strings retrieved fewer than 10 titles. The four subject strings that retrieved fewer than 10 titles were left as is because there seemed to be either no reasonable way to combine them with other categories or a clear expectation that the hit rate would increase gradually over time. For example, the string History \& Archaeology—Regions \& Countries-United States-Local History-Territories, Protectorates, Etc., though yielding only 2 titles, cannot be logically associated with any of the other fifth-level regional categories associated with U.S. local history. The string Languages \& LiteraturesEnglish-English Literature-Individual Authors-2001- , retrieving only 7 titles, is an example of a subject category that is expected to grow. The two Columbia subject categories that required the greatest adjustment were those for Languages \& Literature-English-American Literature, and Languages \& Literatures - English—English Literature, yielding 13,906 and 13,173 title hits respectively, using the unedited Columbia categories. The authors broke these subject strings down into 32 and 33 new categories respectively, in a five-level structure. Table 3 shows 9 of the 33 categories into which the authors split the original subject string, Languages \& Literatures-English-American Literature, in order to bring the retrieval set to within the 10 to 1,000 hit range for each remapped subject string. Thus, hypothetical users of Cornell's revised HILCC scheme for

Table 3. Cornell HILCC Subject Categories for American Literature, with Cornell undergraduate title count (excerpt)

\begin{tabular}{|c|c|c|c|c|c|c|c|c|c|c|}
\hline $\begin{array}{l}\text { Subject } \\
\text { code }\end{array}$ & $\begin{array}{l}\text { Class } \\
\text { la }\end{array}$ & $\begin{array}{c}\text { Class } \\
\text { In }\end{array}$ & $\begin{array}{c}\text { Class } \\
2 a\end{array}$ & $\begin{array}{c}\text { Class } \\
2 n\end{array}$ & $\begin{array}{c}\text { Category } \\
1\end{array}$ & $\begin{array}{c}\text { Category } \\
2\end{array}$ & $\begin{array}{c}\text { Category } \\
3\end{array}$ & $\begin{array}{c}\text { Category } \\
4\end{array}$ & $\begin{array}{c}\text { Category } \\
5\end{array}$ & Count \\
\hline 1203.1 & PS & 1.0000 & PS & 144.9990 & $\begin{array}{l}\text { Languages } \\
\& \text { Literatures }\end{array}$ & English & $\begin{array}{l}\text { American } \\
\text { Literature }\end{array}$ & $\begin{array}{l}\text { History \& } \\
\text { Criticism }\end{array}$ & General & 462 \\
\hline 1203.2 & PS & 147.0000 & PS & 195.9990 & $\begin{array}{l}\text { Languages } \\
\text { \& Literatures }\end{array}$ & English & $\begin{array}{l}\text { American } \\
\text { Literature }\end{array}$ & $\begin{array}{l}\text { History \& } \\
\text { Criticism }\end{array}$ & $\begin{array}{l}\text { Special Classes } \\
\text { of Authors \& } \\
\text { Subjects }\end{array}$ & 234 \\
\hline 1203.3 & PS & 201.0000 & PS & 228.9990 & $\begin{array}{l}\text { Languages } \\
\text { \& Literatures }\end{array}$ & English & $\begin{array}{l}\text { American } \\
\text { Literature }\end{array}$ & $\begin{array}{l}\text { History \& } \\
\text { Criticism }\end{array}$ & $\begin{array}{l}\text { 19th-20th } \\
\text { Centuries } \\
\text { (General) }\end{array}$ & 142 \\
\hline 1203.4 & PS & 241.0000 & PS & 286.9990 & $\begin{array}{l}\text { Languages } \\
\& \text { Literatures }\end{array}$ & English & $\begin{array}{l}\text { American } \\
\text { Literature }\end{array}$ & $\begin{array}{l}\text { History \& } \\
\text { Criticism }\end{array}$ & $\begin{array}{l}\text { Special Regions } \\
\text { \& States }\end{array}$ & 69 \\
\hline 1203.5 & PS & 301.0000 & PS & 379.9990 & $\begin{array}{l}\text { Languages } \\
\& \text { Literatures }\end{array}$ & English & $\begin{array}{l}\text { American } \\
\text { Literature }\end{array}$ & $\begin{array}{l}\text { History \& } \\
\text { Criticism }\end{array}$ & $\begin{array}{l}\text { Poetry, Drama \& } \\
\text { Prose (General) }\end{array}$ & 517 \\
\hline 1203.28 & PS & 3550.0000 & PS & 3553.9990 & $\begin{array}{l}\text { Languages } \\
\& \text { Literatures }\end{array}$ & English & $\begin{array}{l}\text { American } \\
\text { Literature }\end{array}$ & $\begin{array}{l}\text { Individual } \\
\text { Authors }\end{array}$ & 1961-2000, A-C & 763 \\
\hline 1203.29 & PS & 3554.0000 & PS & 3559.9990 & $\begin{array}{l}\text { Languages } \\
\& \text { Literatures }\end{array}$ & English & $\begin{array}{l}\text { American } \\
\text { Literature }\end{array}$ & $\begin{array}{l}\text { Individual } \\
\text { Authors }\end{array}$ & 1961-2000, D-I & 767 \\
\hline 1203.30 & PS & 3560.0000 & PS & 3564.9990 & $\begin{array}{l}\text { Languages } \\
\text { \& Literatures }\end{array}$ & English & $\begin{array}{l}\text { American } \\
\text { Literature }\end{array}$ & $\begin{array}{l}\text { Individual } \\
\text { Authors }\end{array}$ & $1961-2000, \mathrm{~J}-\mathrm{N}$ & 779 \\
\hline 1203.33 & PS & 3600.0000 & PS & 3626.9990 & $\begin{array}{l}\text { Languages } \\
\& \text { Literatures }\end{array}$ & English & $\begin{array}{l}\text { American } \\
\text { Literature }\end{array}$ & $\begin{array}{l}\text { Individual } \\
\text { Authors }\end{array}$ & 2001- & 45 \\
\hline
\end{tabular}


American literature would be able to more precisely specify the subject categories they wished to browse and retrieve a more manageable number of titles with each search, though they would need to drill down an additional two levels in the subject tree to do so.

Tables 4 and 5 illustrate a segment of Columbia HILCC in which more than one subject string covered fewer than 10 titles, an area revised according to the 10 to 1,000 hit range parameters of the project. This reorganization of the "General" category resulted in a 25 percent reduction in the number of categories for that subject area.

Through this two-pronged strategy, the Cornell researchers were able to restructure the Columbia HILCC scheme, developed to provide the underpinning for a Webbased hierarchical menuing system for subject access to that library's collection of electronic resources, into a revised scheme to provide (theoretically) the basis for a similar menuing scheme for subject access to Cornell's undergraduate collection - all with a moderate amount of human intellectual effort. They also demonstrated (again, in theory) that such a framework is scalable up to approximately 150,000 titles.

This menuing scheme is unlikely to be infinitely scalable, however. Mapping the entire Cornell University Library against the revised HILCC categories, using the same 10 to 1,000 title hit range, would require more than 12,000 categories, with significantly more hierarchical tiers, to represent the complete Cornell collection of some 4.4 million titles (the number of Cornell's total holdings in late summer 2004). The authors derived this projection by examining the results of their first attempt to map Columbia HILCC, as is, against Cornell's undergraduate holdings, then calculating the average number of additional subject categories required to bring the retrieval sets of 1,000 titles or more into the desired target range of 10 to 1,000 hits per subject string (see table 6). Then they extracted the call numbers for all 4.4 million titles held by Cornell, mapped them to the revised HILCC scheme, and used the conversion factor derived from the calculation above (2.87) to estimate how many additional subject strings would be

Table 4. Columbia HILCC subject categories for general works, with Cornell undergraduate title count

\begin{tabular}{|c|c|c|c|c|c|c|c|c|}
\hline $\begin{array}{l}\text { Subject } \\
\text { code }\end{array}$ & $\begin{array}{l}\text { Class } \\
\text { la }\end{array}$ & $\begin{array}{c}\text { Class } \\
\text { ln }\end{array}$ & $\begin{array}{c}\text { Class } \\
2 a\end{array}$ & $\begin{array}{l}\text { Class } \\
2 n\end{array}$ & $\begin{array}{c}\text { Category } \\
1\end{array}$ & $\begin{array}{l}\text { Category } \\
2\end{array}$ & $\begin{array}{c}\text { Category } \\
3\end{array}$ & Count \\
\hline 1270 & $\mathrm{AC}$ & 0.0000 & $\mathrm{AC}$ & 799.9990 & General & $\begin{array}{l}\text { Collections \& Series } \\
\text { (General) }\end{array}$ & & 202 \\
\hline “ & $\mathrm{AC}$ & 900.0000 & $\mathrm{AC}$ & 1100.9990 & General & $\begin{array}{l}\text { Collections \& Series } \\
\text { (General) }\end{array}$ & & $* * * * *$ \\
\hline 1004 & $\mathrm{AC}$ & 800.0000 & $\mathrm{AC}$ & 899.9990 & General & Dissertation Indexes & & 0 \\
\hline 1271 & $\mathrm{AE}$ & 0.0000 & $\mathrm{AE}$ & 90.9990 & General & Encyclopedias (General) & & 14 \\
\hline 1272 & $\mathrm{AG}$ & 0.0000 & $\mathrm{AG}$ & 600.9990 & General & Dictionaries (General) & & 25 \\
\hline 1273 & AI & 0.0000 & AI & 122.9990 & General & Indexes (General) & & 13 \\
\hline 1274 & $\mathrm{AM}$ & 0.0000 & $\mathrm{AM}$ & 500.9990 & General & Museum Publications & & 11 \\
\hline 1275 & AN & 0.0000 & AN & 9999.9990 & General & $\begin{array}{l}\text { Newspapers (General } \\
\& \text { Popular) }\end{array}$ & & 2 \\
\hline 1276 & $\mathrm{AP}$ & 0.0000 & $\mathrm{AP}$ & 272.9990 & General & $\begin{array}{l}\text { Periodicals (General } \\
\& \text { Popular) }\end{array}$ & & 94 \\
\hline 1277 & AS & 0.0000 & AS & 945.9990 & General & $\begin{array}{l}\text { Academies \& Learned } \\
\text { Societies Publications }\end{array}$ & & 14 \\
\hline 1278 & AY & 0.0000 & AY & 2001.9990 & General & $\begin{array}{l}\text { Almanacs, Directories } \\
\& \text { Yearbooks (General) }\end{array}$ & & 7 \\
\hline 1279 & $\mathrm{AZ}$ & 0.0000 & $\mathrm{AZ}$ & 999.9990 & General & $\begin{array}{l}\text { History of Scholarship } \\
\& \text { Learning }\end{array}$ & Bibliography & 54 \\
\hline 1294 & Z & 1001.0000 & $\mathrm{Z}$ & 1199.9990 & General & Bibliography & (General) & 53 \\
\hline 1295 & Z & 1200.0000 & $\mathrm{Z}$ & 4999.9990 & General & Bibliography & $\begin{array}{l}\text { Bibliography } \\
\text { (National) }\end{array}$ & 46 \\
\hline 1296 & Z & 5000.0000 & Z & 7999.9990 & General & Bibliography & $\begin{array}{l}\text { Bibliography } \\
\text { (Subject) }\end{array}$ & 45 \\
\hline 1297 & Z & 8000.0000 & Z & 8999.9990 & General & Bibliography & $\begin{array}{l}\text { Bibliography } \\
\text { (Personal) }\end{array}$ & 22 \\
\hline
\end{tabular}

Note: No fourth- and fifth-level subject categories appear in this table excerpt. 
necessary to retrieve 1,000 titles or fewer for each and every string in the scheme (assuming that when mapping the entire Cornell collection, no fewer than 10 hits would be represented in any subject category-an assumption that proved to be correct). An excerpt from the chart representing some of the large, medium, and small retrieval sets revealed in this exercise appears in table 7 .

Thus, although modifying the Columbia HILCC scheme to create a menuing system for a typical ARL undergraduate collection should be possible, HILCC's scalability is limited.
Databases of approximately 150,000 titles may be approaching the limits of a HILCC scheme's effectiveness.

\section{Next Steps: Browsing and Visualization}

As previously noted, the decision to limit retrieval sets in the Cornell remapping of Columbia HILCC to 1,000 titles or fewer was somewhat arbitrary. The presentation of that many search results using a conventional library catalog

Table 5. Cornell HILCC subject categories for General Works, with Cornell undergraduate title count (excerpt)

\begin{tabular}{|c|c|c|c|c|c|c|c|c|}
\hline $\begin{array}{l}\text { Subject } \\
\text { code }\end{array}$ & $\begin{array}{c}\text { Class } \\
\text { la }\end{array}$ & $\begin{array}{c}\text { Class } \\
\text { ln }\end{array}$ & $\begin{array}{c}\text { Class } \\
2 a\end{array}$ & $\begin{array}{l}\text { Class } \\
2 n\end{array}$ & Category 1 & Category 2 & Category 3 & Count \\
\hline 1270 & $\mathrm{AC}$ & 0.0000 & $\mathrm{AC}$ & 799.9990 & General & Collections \& Series (General) & & 202 \\
\hline “ & $\mathrm{AC}$ & 900.0000 & $\mathrm{AC}$ & 1100.9990 & General & Collections \& Series (General) & & $* * * * *$ \\
\hline 1298.1 & $\mathrm{AC}$ & 800.0000 & $\mathrm{AC}$ & 899.9990 & General & $\begin{array}{l}\text { Directories, Indexes, } \\
\text { Information Resources } \\
\text { (General) }\end{array}$ & & 27 \\
\hline “ & AI & 0.0000 & AI & 122.9990 & General & $\begin{array}{l}\text { Directories, Indexes, } \\
\text { Information Resources } \\
\text { (General) }\end{array}$ & & $* * * * *$ \\
\hline “ & AY & 0.0000 & AY & 2001.9990 & General & $\begin{array}{l}\text { Directories, Indexes, } \\
\text { Information Resources } \\
\text { (General) }\end{array}$ & & $* * * * *$ \\
\hline “" & $\mathrm{ZA}$ & 3038.0000 & $\mathrm{ZA}$ & 5199.9990 & General & $\begin{array}{l}\text { Directories, Indexes, } \\
\text { Information Resources } \\
\text { (General) }\end{array}$ & & $* * * * *$ \\
\hline 1271 & $\mathrm{AE}$ & 0.0000 & $\mathrm{AE}$ & 90.9990 & General & Encyclopedias (General) & & 14 \\
\hline 1272 & $\mathrm{AG}$ & 0.0000 & AG & 600.9990 & General & Dictionaries (General) & & 25 \\
\hline 1274 & $\mathrm{AM}$ & 0.0000 & $\mathrm{AM}$ & 500.9990 & General & Museum Publications & & 11 \\
\hline 1275.1 & AN & 0.0000 & AN & 9999.9990 & General & $\begin{array}{l}\text { Newspapers \& Periodicals } \\
\text { (General \& Popular) }\end{array}$ & & 95 \\
\hline “ & AP & 0.0000 & AP & 272.9990 & General & $\begin{array}{l}\text { Newspapers \& Periodicals } \\
\text { (General \& Popular) }\end{array}$ & & $* * * * *$ \\
\hline 1277 & AS & 0.0000 & AS & 945.9990 & General & $\begin{array}{l}\text { Academies \& Learned } \\
\text { Societies Publications }\end{array}$ & & 14 \\
\hline 1279 & $\mathrm{AZ}$ & 0.0000 & $\mathrm{AZ}$ & 999.9990 & General & $\begin{array}{l}\text { History of Scholarship \& } \\
\text { Learning }\end{array}$ & & 54 \\
\hline 1294 & Z & 1001.0000 & Z & 1199.9990 & General & Bibliography & $\begin{array}{l}\text { Bibliography } \\
\text { (General) }\end{array}$ & 53 \\
\hline 1295 & Z & 1200.0000 & Z & 4999.9990 & General & Bibliography & $\begin{array}{l}\text { Bibliography } \\
\text { (National) }\end{array}$ & 46 \\
\hline 1296 & Z & 5000.0000 & Z & 7999.9990 & General & Bibliography & $\begin{array}{l}\text { Bibliography } \\
\text { (Subject) }\end{array}$ & 45 \\
\hline 1297 & Z & 8000.0000 & Z & 8999.9990 & General & Bibliography & $\begin{array}{l}\text { Bibliography } \\
\text { (Personal) }\end{array}$ & 22 \\
\hline
\end{tabular}

Note: No fourth- and fifth-level subject categories appear in this table excerpt. 
interface (or a Google-type interface, for that matter) would be decidedly unwieldy. Even limiting the results to no more than 500 titles or to as few as 200 titles would present obstacles to quick and easy browsability. Before pursuing further work with HILCC schemes, researchers should consider questions of browsability and visualization of search results. How many search results are too many? In a comprehensive investigation of University of California's (UC) MELVYL systemwide library catalog use over 479 days in 1998 and 1999, Cooper found that users of the system, which at the time included the catalogs of nine campuses plus other institutions and some additional citation databases, on average displayed 4 to 5 citations per session, or 2 to 3.5 citations per 100, depending on the database searched. ${ }^{9}$ Cooper highlights the fact that the amount of time users allocated to displaying results was steady across databases, between 30 to 40 seconds per session, and speculates that "one explanation is that irrespective of the database, there are certain motor limits in place when an individual scans citations on a screen that keep the time relatively constant." ${ }^{\text {"10 }}$ Jansen, Spink, and Saracevic discovered from Excite search engine data in 2002 that 58 percent of users look at only the first page of 10 results, 19 percent look at the second page, and 9 percent will go to the third page. ${ }^{11}$ Only a small percentage continue browsing beyond that. They concluded, "any search result beyond the tenth position in the list would be meaningless for $58 \%$ of Web users." ${ }^{2}$ What, then, is the threshold of usefulness for conventional displays of large retrieval sets, or, perhaps more precisely, what is the threshold of their usability? Are the standard modes of presentation of hierarchical menus the best choice for HILCC and similar subject schemes that aim to deliver user-friendly access to large library collections?
The proper response to this last question should be a definitive "no." Although online access to catalog data has sped up and improved users' ability to find and use information about library collections, computer interfaces have, in some ways, reduced the capacity to browse these collections by limiting one's sense of the overall contents of a library. Scrolling through screen after screen of surrogate data is not always a good substitute for moving freely through library stacks, where one's eyes may catch a broad peripheral glimpse of dozens of items at a time, while honing in on particular pieces for one reason or another. While one could argue that browsing a collection through the mediation of a computer monitor, keyboard, and mouse merely calls for a different approach to browsing - a reorientation of browsing techniques - technology should permit a scope that is at least as broad as the traditional library browsing space.

In a 2004 contribution to D-Lib Magazine, Dushay introduced a prototype for just such an online mechanism. ${ }^{13}$ Developed for use with the National Science Digital Library (NSDL), the NSDL Virtual Book Spine Viewer addresses the "focus + context problem"; that is, it optimizes the utility of the browsing software by allowing the user to focus on details, without sacrificing the "larger context of the information space."14 Figure 4 (Virtual Spine Viewer) in Dushay's paper shows how such a browser would work. The frame at the left of the screen contains a subject-based, hierarchical menu that is smaller, but still similar to that of HILCC. The middle frame represents the subject category space in which the "book spines" are arrayed so that they can be seen at a glance. Within what is technically known as a "scatter plot ZUI" (or Zooming User Interface), the titles are scattered along horizontal and vertical axes, over which the user can position a kind of virtual magnifying glass to select poten-

Table 6. Derivation of scaling factor to estimate number of subject categories required to map all of Cornell's holdings to HILCC (excerpt)

\begin{tabular}{|c|c|c|c|c|c|c|}
\hline Subject code & $\begin{array}{l}\text { Title } \\
\text { count }\end{array}$ & $\begin{array}{c}\text { Subject } \\
\text { codes (split) }\end{array}$ & $\begin{array}{l}\text { Subject codes } \\
\text { (split) per } \\
1,000 \text { titles }\end{array}$ & Category 1 & Category 2 & Category 3 \\
\hline 1203 & 13906 & 33 & 2.37 & $\begin{array}{l}\text { Languages \& } \\
\text { Literatures }\end{array}$ & English & American Literature \\
\hline 1130 & 13173 & 34 & 2.58 & $\begin{array}{l}\text { Languages \& } \\
\text { Literatures }\end{array}$ & English & English Literature \\
\hline$\ldots$ & $\cdots$ & $\cdots$ & $\ldots$ & $\ldots$ & $\ldots$ & $\ldots$ \\
\hline 1113 & 1115 & 2 & 1.79 & Social Sciences & $\begin{array}{l}\text { Social Welfare \& } \\
\text { Social Work }\end{array}$ & $\begin{array}{l}\text { Criminology, Penology \& } \\
\text { Juvenile Delinquency }\end{array}$ \\
\hline 1084 & 1059 & 3 & 2.83 & $\begin{array}{l}\text { Business \& } \\
\text { Economics }\end{array}$ & Economics & Industries \\
\hline $\begin{array}{l}\text { Total } \\
\text { (All Subject Codes } \\
\text { With }>1000 \text { Titles) }\end{array}$ & 94823 & 272 & 2.87 & & & \\
\hline
\end{tabular}

Note: No fourth- and fifth-level subject categories appear in this table excerpt. 
tially useful titles in greater bibliographic detail. The upper boxes in the frame at the right allow users to customize the layout of items on the two scatter plot axes by prioritizing two search variables. The lower box in the right frame displays additional bibliographic information pertaining to the book selected. Dushay's virtual book spine viewer provides both focus and context, and creates a browsing environment that more resembles the traditional information space than other online browsing tools. It is one example of a next-generation browser that might allow for better and more useful access to retrieval sets that currently fill more than two or three results screens. Dushay and others doing research into browsing information systems could benefit from an examination of the extensive pre-Web research conducted

Table 7. Application of scaling factor to estimate number of subject categories required to map all of Cornell's holdings to HILCC (excerpt)

\begin{tabular}{|c|c|c|c|c|c|c|c|c|}
\hline $\begin{array}{l}\text { Subject } \\
\text { code }\end{array}$ & $\begin{array}{l}\text { Title } \\
\text { count }\end{array}$ & $\begin{array}{l}\text { Scaling } \\
\text { factor }\end{array}$ & $\begin{array}{l}\text { Total no. } \\
\text { of subject } \\
\text { codes (split) } \\
\text {-- estimate }\end{array}$ & $\begin{array}{c}\text { Category } \\
1\end{array}$ & $\begin{array}{c}\text { Category } \\
2\end{array}$ & $\begin{array}{c}\text { Category } \\
3\end{array}$ & $\begin{array}{c}\text { Category } \\
4\end{array}$ & $\begin{array}{c}\text { Category } \\
5\end{array}$ \\
\hline 1035.1 & 126156 & 2.87 & 362.07 & $\begin{array}{l}\text { Music, Dance, } \\
\text { Drama \& Film }\end{array}$ & Music & & & \\
\hline 1225.1 & 119708 & 2.87 & 343.56 & $\begin{array}{l}\text { Art, Architecture } \\
\text { \& Applied Arts }\end{array}$ & Fine Arts & & & \\
\hline 1267.1 & 112593 & 2.87 & 323.14 & $\begin{array}{l}\text { Languages \& } \\
\text { Literatures }\end{array}$ & $\begin{array}{l}\text { East Asian \& } \\
\text { Ural-Altaic } \\
\text { Languages \& } \\
\text { Literatures }\end{array}$ & & & \\
\hline 1536.1 & 103292 & 2.87 & 296.45 & Sciences & $\begin{array}{l}\text { Agriculture \& } \\
\text { Animal Sciences }\end{array}$ & & & \\
\hline$\cdots$ & $\cdots$ & $\cdots$ & $\cdots$ & $\cdots$ & $\cdots$ & $\cdots$ & $\ldots$ & $\ldots$ \\
\hline 1503 & 1053 & 2.87 & 3.02 & $\begin{array}{l}\text { Law, Politics \& } \\
\text { Government }\end{array}$ & $\begin{array}{l}\text { Military \& } \\
\text { Naval Science }\end{array}$ & $\begin{array}{l}\text { Military } \\
\text { Engineering }\end{array}$ & & \\
\hline 1549.1 & 1019 & 2.87 & 2.92 & $\begin{array}{l}\text { Law, Politics \& } \\
\text { Government }\end{array}$ & $\begin{array}{l}\text { Government } \\
\text { (Non-U.S.) }\end{array}$ & $\begin{array}{l}\text { Government } \\
\text { (Canada) }\end{array}$ & & \\
\hline 1258 & 998 & 2.87 & 1.00 & $\begin{array}{l}\text { Philosophy \& } \\
\text { Religion }\end{array}$ & Religion & $\begin{array}{l}\text { North \& South } \\
\text { American } \\
\text { Religions }\end{array}$ & & \\
\hline 1221.11 & 976 & 2.87 & 1.00 & $\begin{array}{l}\text { Philosophy \& } \\
\text { Religion }\end{array}$ & Philosophy & Renaissance & & \\
\hline$\cdots$ & $\cdots$ & $\ldots$ & $\ldots$ & $\cdots$ & $\cdots$ & $\ldots$ & $\ldots$ & $\ldots$ \\
\hline 1532.1 & 135 & 2.87 & 1.00 & $\begin{array}{l}\text { Law, Politics \& } \\
\text { Government }\end{array}$ & $\begin{array}{l}\text { Military \& } \\
\text { Naval Science }\end{array}$ & $\begin{array}{l}\text { Space Warfare } \\
\& \text { Surveillance }\end{array}$ & & \\
\hline 1100.2 & 119 & 2.87 & 1.00 & Social Sciences & $\begin{array}{l}\text { Recreation \& } \\
\text { Sports }\end{array}$ & $\begin{array}{l}\text { Auto Travel \& } \\
\text { Racing }\end{array}$ & & \\
\hline & & & & & & $\begin{array}{l}\text { Psychotropic } \\
\text { Drugs \& Other }\end{array}$ & & \\
\hline 1253.1 & 64 & 2.87 & 1.00 & Social Sciences & Psychology & Substances & & Territories, \\
\hline 1009.6 & 30 & 2.87 & 1.00 & $\begin{array}{l}\text { History \& } \\
\text { Archaeology }\end{array}$ & $\begin{array}{l}\text { Regions \& } \\
\text { Countries }\end{array}$ & United States & $\begin{array}{l}\text { Local } \\
\text { History }\end{array}$ & $\begin{array}{l}\text { Protectorates, } \\
\text { Etc. }\end{array}$ \\
\hline $\begin{array}{l}\text { Total (All } \\
\text { Subject } \\
\text { Codes) }\end{array}$ & 4462395 & & 12772.91 & & & & & \\
\hline
\end{tabular}


on browsing online library catalogs, summarized by Kurth and Peters. ${ }^{15}$

\section{Conclusion}

Although the research described in this paper stopped short of actually building and implementing an interface with which to provide bibliographic access to a virtual undergraduate collection, a library might put the Columbia and Cornell HILCC schemes to other uses. A complete histogram of hit rates across all HILCC categories, such as the one developed in this study, might be a useful tool for analyzing the subject scope of an existing collection-whether destined for undergraduates or delimited by other user or subject criteria. Further, if holdings in a given collection were mapped periodically against the same HILCC categories, the results might paint a revealing picture of how recent additions reflect (or do not reflect) the pre-existing or presumed subject orientation of that collection and how its subject focus might be changing. HILCC tables also could be used to analyze interlibrary loan trends and patterns (a use to which Columbia has reportedly begun to apply Cornell's revised HILCC scheme). One could even envision the merger of all three of these data sets into a single graph to track the direction of collection growth and demand over time.

There are clearly several directions in which further research might go. It is not yet clear whether the Cornell University Library will implement a HILCC-based interface to provide bibliographic access to its physically collocated current undergraduate collection or, in the future, to a physically dispersed collection, if space concerns on the central campus demand such redistribution of the physical material. As the Columbia University Library did, the authors invite other institutions to pick up where they have left off, to adopt and customize Cornell's modified HILCC scheme for use in their own collections and within their own institutional contexts, and to explore further the possibility of using scatter plot ZUIs, hyperbolic trees, and other information visualization techniques to present HILCC data optimally to the end user.

At a philosophical level, the problems with hierarchical classification, even with an improved display, run deep. Shirky recently argued in "Ontology Is Overrated: Categories, Links, and Tags" that the evolution of the Web itself shows the inherent brittleness of all attempts at authoritative classification for very large domains. ${ }^{16}$ The most ambitious attempt at classifying the Web may be Yahoo!'s, but who uses their classification now? Rather than trying to impose ordered classification on users, what may work better is to allow users themselves to classify things any way they see fit and to create order and paths of exploration derived from the raw data. The success of Google searching, based as it is on links across Web sites, is the best example of such an approach. Those who pursue further research on the creation of virtual collections will need to focus on this trend as well.

\section{References and Notes}

1. Stephen Paul Davis, "HILCC: A Hierarchical Interface to Library of Congress Classification," Journal of Internet Cataloging 5, no. 4 (2002): 19-49.

2. Ibid., 19 .

3. Ibid., 21.

4. Columbia University Library, "E-Journals Subject Browse," www.columbia.edu/cu/lweb/eresources/ejournals/subjects (accessed May 27, 2005).

5. Davis, "HILCC," 40. As noted in table 2 of the current paper, Columbia's e-resource holdings have now exceeded 50,000 titles.

6. Association of Research Libraries, "Introduction," Library Storage Facilities, Management, and Services, SPEC Kit, 242 (Washington, D.C.: ARL, May 1999), www.arl.org/spec/242fly .html (accessed Dec. 29, 2005).

7. University of Texas Libraries, "Relocation of UGL Book Collection to Begin," www.lib.utexas.edu/about/news/ fac-bookrelocation.html (accessed May 27, 2005).

8. See Section II, Step 3 of the Cornell HILCC project log for more on these scripts and the way they interact-www .library.cornell.edu/cts/browseandextend (accessed May 27, 2005).

9. Michael D. Cooper, "Usage Patterns of a Web-based Library Catalog," Journal of the American Society for Information Science and Technology 52, no. 2 (Jan. 15, 2001): 145.

10. Ibid.

11. Bernard J. Jansen, Amanda Spink, and Tefko Saracevic, "Real Life, Real Users, and Real Needs: A Study and Analysis of User Queries on the Web," Information Processing and Management 36 (Mar. 2000): 207-27.

12. Ibid., 214.

13. Naomi Dushay, "Visualizing Bibliographic Metadata: A Virtual (Book) Spine Viewer," D-Lib Magazine 10, no. 10 (2004), www.dlib.org/dlib/october04/dushay/10dushay.html (accessed May 27, 2005).

14. Ibid.

15. Martin Kurth and Thomas A. Peters, eds., Browsing in Information Systems: An Extensive Annotated Bibliography of the Literature (Ann Arbor, Mich.: Pierian Pr., 1995).

16. Clay Shirky, "Ontology Is Overrated: Categories, Links, and Tags," www.shirky.com/writings/ontology_overrrated.html (accessed May 27, 2005). 